\title{
Advances in Rapid Condition Assessments of Rock Art Sites: Rock Art Stability Index (RASI)
}

Niccole V. Cervenya, Ronald I. Dorn ${ }^{\mathrm{b}}$, Casey D. Allenc ${ }^{\mathrm{c}}$ David S. Whitley ${ }^{\mathrm{d}}$

\author{
Keywords: \\ condition assessment \\ erosion \\ rock art \\ weathering \\ rock decay
}

\begin{abstract}
The Rock Art Stability Index (RASI) is a rapid, quantitative approach to rock art condition assessment. Research carried out at Petrified Forest National Park, USA, demonstrates that, following a 2-day training session, site evaluators obtained replicable results, facilitating a condition assessment of over 3500 engraved panels. Two electron microscopy case studies allowed us to identify the specific rock decay processes and major causes of destruction on panels that were RASI-scored as in
\end{abstract}


46 high threat, suggesting potential avenues for future conservation interventions. This 47 approach illustrates a holistic strategy for rock art conservation.

48 
1. Introduction

Rock art sites are especially vulnerable to human and natural damage, and they are difficult to manage and conserve (ICOMOS, 2000; Loubser 2001; Whitley 2001, 2005; Bertilsson, 2002; J.Paul Getty Trust, 2003; Varner, 2003; Keyser et al., 2005; Berltilsson, 2015; Haubt, 2015). They are also more common than often recognized: there are over 1,500 recorded rock art sites in California alone, e.g., representing literally millions of individual motifs. One result is an unmet conservation need, partly exacerbated by the fact that traditional conservation approaches, involving individual conservators each using their preferred assessment approach, are time consuming and idiosyncratic. Another is that rock art conservation commonly reduces to crisis-management: conservation interventions undertaken only after serious threats to the art are observed. The long-term sustainability of rock art requires rapid, replicable analytical assessment techniques that are efficient and inexpensive, allowing for practical management planning. One approach that meets these goals is the Rock Art Stability Index (RASI; Dorn et al., 2008; Allen, 2011; Allen et al., 2011; Allen and Lukinbeal, 2011; Allen and Groom, 2013; Cerveny et al., 2016), which provides a quantitative evaluation of rock panel decay.

Most panel decay analyses involve specialized equipment and training (e.g., Fitzner et al., 2004; Campbell, 1991; Vogt and Edsall, 2010; Plisson and Zotkina, 2015; Hoerle and Salomon, 2004; Hoerle, 2006; Guo and Jiang, 2015; Yun et al., 
72 2015; Hall et al., 2007; Mol and Preston, 2010; Linderholm et al., 2015; Tratebas et

73 al., 2004; Pillans and Fifield, 2013). While valuable, these specialized analyses

74 logically should follow a holistic management strategy directed first at identifying

75 relative degrees of site vulnerability (e.g., Loubser 2001; Warke et al., 2003; Giesen

76 et al., 2014; Carmichael, 2016), such as RASI. We present here new data

77 demonstrating that the RASI approach is replicable with minimal training, and that

78 its results are supported by electron microscopy studies.

80 2. The RASI Method

81 RASI provides a rapid assessment of rock art site condition. It was designed

82 for use by college students, volunteers and archaeologists, following a minimum

83 amount of training. It provides a replicable rank ordering of various aspects of

84 panel physical condition, yielding a score of relative site vulnerability. When used

85 regionally and comparatively, it identifies those sites in greatest threat, thereby

86 establishing priorities for detailed site management and conservation interventions.

87 It is not intended as a method for conserving individual rock art sites. Instead, it

88 promotes logical management planning and conservation resource allocations.

89 After a 2-day training session, individual RASI evaluators are capable of

90 identifying and judging the severity of the physical conditions at a site, scoring with

91 the form presented in Table 1. Five primary analytical categories are included (Fig.

92 1): (1) fundamental weaknesses in the bedrock supporting a rock art site that

93 facilitate erosion; (2) aspects of the support rock that can result in rock art panel

94 detachment; (3) incremental erosion; (4) loss of large blocks of a rock panel; and (5) 
95 natural rock coatings and other deposits that either stabilize or promote

96 instability. A final and flexible sixth category is also incorporated in the index (Table

97 1). This allows for the inclusion of region-specific concerns (such as human

98 vandalism), and the differential weighting of this or any of the other categories in

99 the calculation of an individual index score for a site.

100

101 [FIGURE 1 ABOUT HERE]

102

103

Several online resources facilitate RASI's use. A series of online presentations

104 are available:

105

106

107

108

109

110

111

112

113 An atlas illustrating examples of the different physical conditions and

114 variables can be seen at:

115 http://alliance.la.asu.edu/rockart/stabilityindex/RASIAtlas.html

116 In addition, brief 1-page handouts on each RASI component can be downloaded

117 from this site: http://alliance.la.asu.edu/rockart/NSF/RASI Tidbits.html

118

119 3. Petrified Forest National Park Case Study 
120 In an interdisciplinary field based research experience for undergraduates,

121 first and second year college students were trained to conduct RASI analysis on

122 sandstone petroglyph panels. Training typically spanned 4 hours in an interactive

123 seminar and another hour working together on the same rock art panel in the field.

124 The first individual assessments took approximately 45 minutes with expert

125 consultation, decreasing in time as terminology and field observations became more

126 familiar. Students participated in field research lasting from 2 days to 2 weeks, 7

127 hours per day, assessing total of 100-150 panels per day. Two to three trips per

128 academic semester were conducted between 2009-2012. In all over 3500 panels

129 were analyzed by students. Assessment of student RASI scores for specific panels

130 resulted in $<5 \%$ variance on their scores.

131 Testing groups of trained college students demonstrates that the results for

132 any given site are replicable between evaluators (Allen and Lukinbeal, 2010; Allen,

133 2011; Allen et al., 2011a; Allen and Groom, 2013). A video presentation illustrating

134 the RASI evaluation of engraved panels at Petrified Forest National Park can be

135 viewed here: https://www.youtube.com/watch?v=QbhRahgRzg4 . In all over 3500

136 panels were analyzed by students.

137 The total RASI scores provide site managers with a quick measure of the

138 overall condition of a panel (e.g., Fig. 2). Total RASI scores of greater than 30 alert

139 conservation resource managers to panels that have multiple conservation

140 problems. In addition, each specific RASI scoring element also has value in

141 evaluating panel instability. For example, Fig. 3 presents the data gathered by

142 students for panels that lack support at the base or undercutting, where mass 
143 wasting could topple the panel. In another example, Fig. 4 presents observations

144 related to anthropogenic impacts on a panel, regardless of cause. The power of RASI,

145 as exemplified by its use at just one U.S. National Park, is its ability to provide

146 widespread, replicable and rapid condition assessment. To our knowledge, no other

147 rock art condition assessment strategy has yet been applied over such a large area.

148

149 [FIGURE 2 ABOUT HERE]

150

151 [FIGURE 3 ABOUT HERE]

152

153 [FIGURE 4 ABOUT HERE]

154

155 4. Comparison of RASI with Electron Microscope Studies

156 After RASI identifies a panel in potential danger, a next step would be to

157 carry out more detailed studies to evaluate the process(es) that could lead to panel

158 loss. Then, only after these processes are understood, should conservation

159 intervention measures (Loubser, 2001) be taken. We present here two examples of

160 RASI case studies and how they compare with electron microscopic analyses.

$161 \quad$ Fig. 5 presents a Petrified Forest National Park panel located near Lacey

162 Point. The scored panel has an overall RASI average score of 34 with scores of 3

163 (dominant issue) identified for scaling, undercutting, loss parallel to stone structure,

164 flaking, weathering-rind development, and vandalism. Electron microscope

165 observations on a sample collected at the white arrow in Fig. 5 indicate the cause of 
166 scaling of the panel. Motifs engraved into dark rock varnish have been lost through

167 ongoing mineral dissolution underneath the rock varnish. The dashed white line in

168 the SEM imagery separates two different zones in the weathering rind of the

169 sandstone: a zone of decay underneath and a zone of enhanced porosity with

170 organics above the rind. The next effect of decayed rock, enhanced porosity, and

171 endolithic organisms results in scaling of the panel face.

172

173 [FIGURE 5 ABOUT HERE]

174

175 Fig. 6 presents a McDowell Mountains, central Arizona, USA, panel with an

176 overall RASI score of 42 and with scores of 3 (dominant issue) identified for plant

177 growth, flaking of the weathering-rind, weathering-rind development, lithobiont

178 (organisms directly growing on rock surfaces such as lichens, fungi or algae) pitting,

179 lithobiont release, textural anomalies and splintering. The visual loss of the motifs is

180 due to the action of microcolonial fungi lithobionts, as revealed by SEM imagery.

181

182 [FIGURE 6 ABOUT HERE]

183

184

185 In these two cases (Figs. 5-6), RASI identified each panel as endangered.

186 Electron microscopy next allowed us to identify specific decay process and the

187 major causes of panel destruction, suggesting future potential conservation

188 intervention approaches. These examples illustrate a logical and holistic approach 
189 to rock art conservation, starting first with the identification of endangered panels

190 on a regional scale, followed by more detailed analytical studies to determine causes

191 of destruction, from which potential corrective measures could be identified.

192

193 5. Conclusion

194 Over twenty different strategies can be used to analyze rock art panel decay

195 (Dorn et al., 2008). Unfortunately, these approaches are too specialized, expensive,

196 and/or time consuming to use on a regional scale. It is thus essential, for practical

197 management and efficient resource allocations, that rapid condition assessment

198 approaches be adopted. Our study at the Petrified Forest National Park, USA,

199 illustrates the power and ease of the Rock Art Stability Index as an effective

200 management and conservation tool.

201

202 Acknowledgements.

203 We thank Elyssa Gutbrod and Steve Gibson for their assistance in the GIS

204 analysis of the Petrified Forest National Park data. Prior collaboration with Trinkle

205 Jones allowed collection of the petroglyph sample at Petrified Forest National Park.

206 We also thank National Park Service Cultural Resource Anthropologists William

207 Reitze and Jason Theuer for providing access to rock art sites at Petrified Forest

208 National Park. Field evaluations were completed by students from Mesa Community

209 College and the University of Colorado - Denver. This material is based upon work

210 supported by the National Science Foundation under Grant Nos. DUE-0837451,

211 DUE-0837051, DUE-0836812. Any opinions, findings, and conclusions or 
recommendations expressed in this material are those of the author(s) and do not

necessarily reflect the views of the National Science Foundation.

214

215

216

217

218

219

220

221

222

223

224

225

226

227

228

229

230

231

232

233

234

235

236

237

238

239

240

241

242

243

244

245

246

247

248

249

250

251

252

253

\section{References}

Allen, C.D., 2011. Concept mapping validates fieldwork's capacity to deepen students' cognitive linkages of complex processes. Research in Geographic Education 13, $30-51$.

Allen, C.D., Cutrell, A.K., Cerveny, N.C., Theurer, J., 2011. Advances in rock art field assessment. La Pintura February Issue, 4-6, 13.

Allen, C.D., Groom, K.M., 2013. Evaluation of Granada's "Carib Stones" via the Rock Art Stability Index. Applied Geography 42, 165-175.

Allen, C.D., Lukinbeal, C., 2010. Practicing physical geography: An actor-network view of physical geography exemplified by the rock art stability index. Progress in Physical Geography 35, 227-248.

Berltilsson, U., 2015. Rock art at Risk. Heritage at Risk 2006/2007, 172-174.

Bertilsson, R., 2002. Rock art at Risk. http://www.international.icomos.org/risk/2002/rockart2002.htm (accessed 3/8/05).

Campbell, I.A., 1991. Classification of rock weathering at Writing-On-Stone Provincial Park, Alberta, Canada. Earth Surface Processes and Landforms 16, 701-711.

Carmichael, B., 2016. Supporting Indigenous rangers' management of climate-change impacts on heritage sites: developing an effective planning tool and assessing its value. The Rangeland Journal 37, 597-607.

Cerveny, N.V., Allen, C., Gutbrod, E., Gibson, S., Dorn, R.I., Gordon, S.J., Whitley, D.S., 2016. Welcome to RASI - Rock Art Stability Index. http://alliance.la.asu.edu/rockart/stabilityindex/RASI_Overview.html (last accessed January 16, 2016).

Cerveny, N.V., Kaldenberg, R., Reed, J., Whitley, D.S., Simon, J., Dorn, R.I., 2006. A new strategy for analyzing the chronometry of constructed rock features in deserts. Geoarchaeology 21, 181-203.

Dorn, R.I., Whitley, D.S., Cerveny, N.C., Gordon, S.J., Allen, C., Gutbrod, E., 2008. The rock art stability index: A new strategy for maximizing the sustainability of rock art as a heritage resource. Heritage Management 1, 35-70.

Fitzner, B., Heinrichs, K., LaBouchardiere, D., 2004. The Bangudae petroglyph in Ulsan, Korea: studies on weathering damage and risk prognosis. Environmental Geology 46, 504-526.

Giesen, M.J., Ung, A., Warke, P.A., Christgen, B., Mazel, A.D., Graham, D.W., 2014. Condition assessment and preservation of open-air rock art panels during environmental change. Journal of Cultural Heritage 15, 49-56.

Guo, F., Jiang, G., 2015. Investigation into rock moisture and salinity regimes: implications of sandstone weathering in Yungang Grottoes, China. Carbonates and Evaporites 30, 1-11. 
Hall, K., Meiklejohn, I., Arocena, J., 2007. The thermal responses of rock art pigments: Implications for rock art weathering in southern Africa. Geomorphology 91, 132145.

Hall, K., Thorn, C., \& Sumner, P. 2012. On the persistence of 'weathering'. Geomorphology 149, 1-10.

Haubt, R.A., 2015. The global rock art database: developing a rock art reference model for the RADB system using the CIDOC CRM and Australian heritage examples. ISPRS Annals of Photogrammetry, Remote Sensing and Spatial Information Sciences 1, 89-96.

Hoerle, S., 2006. Rock temperatures as indicator of weathering processes affecting rock art. Earth Surface Processes and Landforms 31, 383-389.

Hoerle, S., Salomon, A., 2004. Microclimatic data and rock art conservation at Game Pass Shelter in the Kamberg Nature Reserve, KwaZulu-Natal. South African Journal of Science 100, 340-341.

ICOMOS, 2000. International Scientific Committee on Rock Art. http://www.international.icomos.org/risk/isc-rockart_2000.htm (accessed 3/5/05).

J.PaulGettyTrust, 2003. Conservation of rock art. http://www.getty.edu/conservation/education/rockart/ accessed July 9, 2005.

Keyser, J.D., Greer, M., Greer, J., 2005. Arminto petroglyphs: Rock art damage assessment and management considerations in Central Wyoming. Plains Anthropologist 50, 23-30.

Linderholm, J., Geladi, P., Sciuto, C., 2015. Field-based near infrared spectroscopy for analysis of Scandinavian Stone Age rock paintings. Journal of Near Infrared Spectroscopy 23, 227-236.

Loubser, J., 2001. Management planning for conservation. In: Whitley, D.S. (Ed.), Handbook for rock art research. Altamira Press, Walnut Creek, pp. 80-115.

Mol, L., Preston, P.R., 2010. The writing's in the wall: a review of new preliminary applications of electrical resistivity tomography within archaeology. Archaeometry 52, 1079-1095.

Pillans, B., Fifield, L.K., 2013. Erosion rates and weathering history of rock surfaces associated with Aboriginal rock art engravings (petroglyphs) on Burrup Peninsula, Western Australia, from cosmogenic nuclide measurements. Quaternary Science Reviews 69, 98-106.

Plisson, H., Zotkina, L.V., 2015. From 2D to 3D at macro-and microscopic scale in rock art studies. Digital Applications in Archaeology and Cultural Heritage 2, 102-119.

Tratebas, A.M., Cerveny, N., Dorn, R.I., 2004. The effects of fire on rock art: Microscopic evidence reveals the importance of weathering rinds. Physical Geography 25, 313-333.

Varner, G.R., 2003. The destruction of America's Cultural Resources. http://www.authorsden.com/visit/viewarticle.asp?AuthorID=1215\&id=10400 (accessed 3/8/05).

Vogt, B.J., Edsall, R.M., 2010. Terrestrial laser scanning and exploratory spatial data analysis for the mapping of weathering forms on rock art panels. Geocarto International 25, 347-367. 
298 Warke, P.A., Curran, J.M., Turkington, A.V., Smith, B.J., 2003. Condition assessment for 299 building stone conservation: a staging system approach. Building and $300 \quad$ Environment 38, 1113-1123.

301 Whitley, D.S. (Ed.), 2001. Handbook of Rock Art Research. Altamira Press.

302 Whitley, D.S., 2005. Introduction to Rock Art Research. Left Coast Press, Walnut Creek. 303 Yun, F., Liang, Q., Shaojun, Y., Pengcheng, P., Qiuping, Z., 2015. Mechanisms of Rock

$304 \quad$ Cracking on Huashan Rock Paintings. Engineering Geology for Society and

305 Territory $8,147-151$.

306

307

308 
Table 1. General categories of weathering forms and ordinal scale used to classify rock art decay on a panel.

\begin{tabular}{|c|c|c|c|c|}
\hline Site Setting (geological factors) & $\begin{array}{c}\text { not } \\
\text { present }\end{array}$ & present & obvious & dominant \\
\hline $\begin{array}{l}\text { Fissures independent of stone lithification (pressure } \\
\text { release, calcrete wedging) }\end{array}$ & 0 & 1 & 2 & 3 \\
\hline $\begin{array}{l}\text { Fissures dependent on lithification (bedding, } \\
\text { foliations) }\end{array}$ & 0 & 1 & 2 & 3 \\
\hline Changes in textural anomalies (banding, concretions) & 0 & 1 & 2 & 3 \\
\hline $\begin{array}{l}\text { Rock weakness (Moh's hardness tested at control } \\
\text { site; } 3-<4,2-\text { Moh4-5, 1-Moh6-8, 0-Moh7+) }\end{array}$ & 0 & 1 & 2 & 3 \\
\hline
\end{tabular}

\begin{tabular}{|c|c|c|c|c|}
\hline Weaknesses of the Rock Art Panel & $\begin{array}{c}\text { not } \\
\text { present }\end{array}$ & present & obvious & dominant \\
\hline Fissuresol (future location of break-off) & 0 & 1 & 2 & 3 \\
\hline Roots & 0 & 1 & 2 & 3 \\
\hline Plant growth near or on panel & 0 & 1 & 2 & 3 \\
\hline $\begin{array}{l}\text { Scaling } \& \text { flaking (future location of flaking - } \\
\text { millimeter-scale, or scaling }- \text { centimeter-scale) }\end{array}$ & 0 & 1 & 2 & 3 \\
\hline $\begin{array}{l}\text { Splintering (following stone structures and oblique to } \\
\text { surface) }\end{array}$ & 0 & 1 & 2 & 3 \\
\hline Undercutting & 0 & 1 & 2 & 3 \\
\hline Weathering-rind development & 0 & 1 & 2 & 3 \\
\hline Other concerns (e.g. water flow) & 0 & 1 & 2 & 3 \\
\hline
\end{tabular}

\section{Evidence of Large Erosion Events On and Below the Panel $\begin{gathered}\text { not } \\ \text { present present obvious dominant }\end{gathered}$}

$\begin{array}{lllll}\text { Anthropogenic activities } & 0 & 1 & 2 & 3 \\ \begin{array}{l}\text { Fissuresol/calcrete wedging (or dust in fissuresol, or } \\ \text { both) }\end{array} & 0 & 1 & 2 & 3 \\ \begin{array}{l}\text { Fire } \\ \text { Undercutting }\end{array} & 0 & 1 & 2 & 3 \\ \begin{array}{l}\text { Other natural causes of break-off (wedgework of } \\ \text { roots, earthquakes, intersection of fractures, ...) }\end{array} & 0 & 1 & 2 & 3 \\ \end{array}$




\section{EVIDENCE ON SMALL EROSION EVENTS ON THE PANEL}

not

present present obvious dominant

\begin{tabular}{|c|c|c|c|c|}
\hline Abrasion (from sediment transport by water) & 0 & 1 & 2 & 3 \\
\hline $\begin{array}{l}\text { Anthropogenic cutting (carving, chiseling, bullet } \\
\text { impact, ...) }\end{array}$ & 0 & 1 & 2 & 3 \\
\hline Aveolization (honeycombed appearance) & 0 & 1 & 2 & 3 \\
\hline $\begin{array}{l}\text { Crumbly disintegration (in groups of grains or } \\
\text { powdery) }\end{array}$ & 0 & 1 & 2 & 3 \\
\hline Flaking (single or multiple; millimeter-scale) & 0 & 1 & 2 & 3 \\
\hline Flaking of the weathering rind & 0 & 1 & 2 & 3 \\
\hline $\begin{array}{l}\text { Granular disintegration (most frequently sandstone } \\
\text { and granitic) }\end{array}$ & 0 & 1 & 2 & 3 \\
\hline Lithobiont pitting & 0 & 1 & 2 & 3 \\
\hline $\begin{array}{l}\text { Lithobiont release (when the "dam" of weathered } \\
\text { rind decayed rock erodes) }\end{array}$ & 0 & 1 & 2 & 3 \\
\hline Loss parallel to stone structure (bedding or foliations) & 0 & 1 & 2 & 3 \\
\hline $\begin{array}{l}\text { Rock coating detachment (usually incomplete; } \\
\text { includes paint material in pictographs) }\end{array}$ & 0 & 1 & 2 & 3 \\
\hline $\begin{array}{l}\text { Rounding of petroglyph edges (or blurring of } \\
\text { pictograph images) }\end{array}$ & 0 & 1 & 2 & 3 \\
\hline Scaling (centimeter-scale; thicker than flaking) & 0 & 1 & 2 & 3 \\
\hline $\begin{array}{l}\text { Textural anomaly features erode differentially (clay } \\
\text { lenses, cementation differences, nodules) }\end{array}$ & 0 & 1 & 2 & 3 \\
\hline $\begin{array}{l}\text { Splintering (following stone structures and oblique to } \\
\text { stone surface) }\end{array}$ & 0 & 1 & 2 & 3 \\
\hline $\begin{array}{l}\text { Other forms of incremental erosion (e.g. insects, } \\
\text { birds) }\end{array}$ & 0 & 1 & 2 & 3 \\
\hline
\end{tabular}

\begin{tabular}{lcccc}
\hline Rock coatings on the Panel & $\begin{array}{c}\text { not } \\
\text { present }\end{array}$ & present & obvious & dominant \\
\hline Anthropogenic (chalking, graffiti, other) & 0 & 1 & 2 & 3 \\
Rock coating present & 0 & -1 & -2 & -3 \\
Case hardening (deposits in rock that harden outer & 0 & -1 & -2 & -3 \\
shell) & 0 & 1 & 2 & 3 \\
Salt Efflorescence or subflorescence & 0 & \\
\hline
\end{tabular}

\section{Highlighting Vandalism and other Issues}

Concerns Please briefly describe the problem and why you believe that this concern endangers the panel. Put in " $X$ " on the right to indicate whether this concern creates a "severe danger", "great danger", "urgent danger" or "problem" for the panel.

Graffiti

Other 
Vandalism

(describe)

Trash

Visitor impact

(e.g. dust, trail

proximity)

Land use

issues (e.g.

livestock, off-

road vehicles)

Natural

processes that

are a major

concern to you

Notations on Rock Coatings (note: these notes do not alter the Rock Art Stability Index Score, but they are useful in analyzing a site's context)

Less difficult to identify in the field

\begin{tabular}{ll}
\hline Rock Coating & Circle One \\
\hline Lithobionts (e.g. lichen) & Yes / No / Uncertain \\
Rock Varnish (desert & Yes / No / Uncertain \\
varnish) & \\
Bird Excrement & Yes / No / Uncertain \\
Dust Coatings & Yes / No / Uncertain \\
Iron Film & Yes / No / Uncertain \\
\hline
\end{tabular}

More difficult coatings to identify in the field

\begin{tabular}{lll}
\hline Rock Coating & Circle One & Notes \\
\hline Silica glaze & Yes / No / Uncertain & \\
Heavy metal & Yes / No / Uncertain \\
Oxalate & Yes / No / Uncertain \\
\hline
\end{tabular}


Cerveny et al - Figure Captions

Fig. 1 The general sequence of field observations in the RASI index.

Fig. 2. RASI total scores for 16 panels at a public overlook at Petrified Forest National Park, superimposed on the U.S. Geological Survey topographic map. Higher scores indicate greater danger. While not cartographically appealing, this map was generated in the field after the panels were scored.

Fig. 3. Scores for undercutting measured at 450 panels at Petrified Forest National Park. The score of 3 indicates panels where undercutting was considered to be dominant and of serious concern.

Fig. 4. Scores for all anthropogenic impacts measured at 450 panels at Petrified Forest National Park. The score of 3 indicates panels where scorers felt the impacts were dominant and represent the greatest danger.

Fig. 5. Petrified Forest National Park panel near Lacey Point exhibits panel scaling. The upper and lower SEM images are secondary electrons (showing topography) and back-scattered electrons (showing atomic number).

Fig. 6. Hohokam motifs engraved into dark rock varnish on a metarhyolite alluvial-fan boulder. The motifs are disappearing due to the secretion of organic acids by microcolonial fungi, where the rounded forms $\sim 5 \mu \mathrm{m}$ diameter are individual cells. The secondary electron image on the left shows an abundance of fungi dissolving the varnish away, resulting in loss of the motifs. 
Step 1

\section{Site Context}

Step 2

Weaknesses

of the Panel

Step 3

Step 4

Evidence of Small

Erosion Events on the Panel

Step 5

Rock Coatings on the Panel

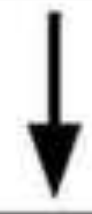

Highlighting Vandalism

Step 6 and other Modern

Problems 


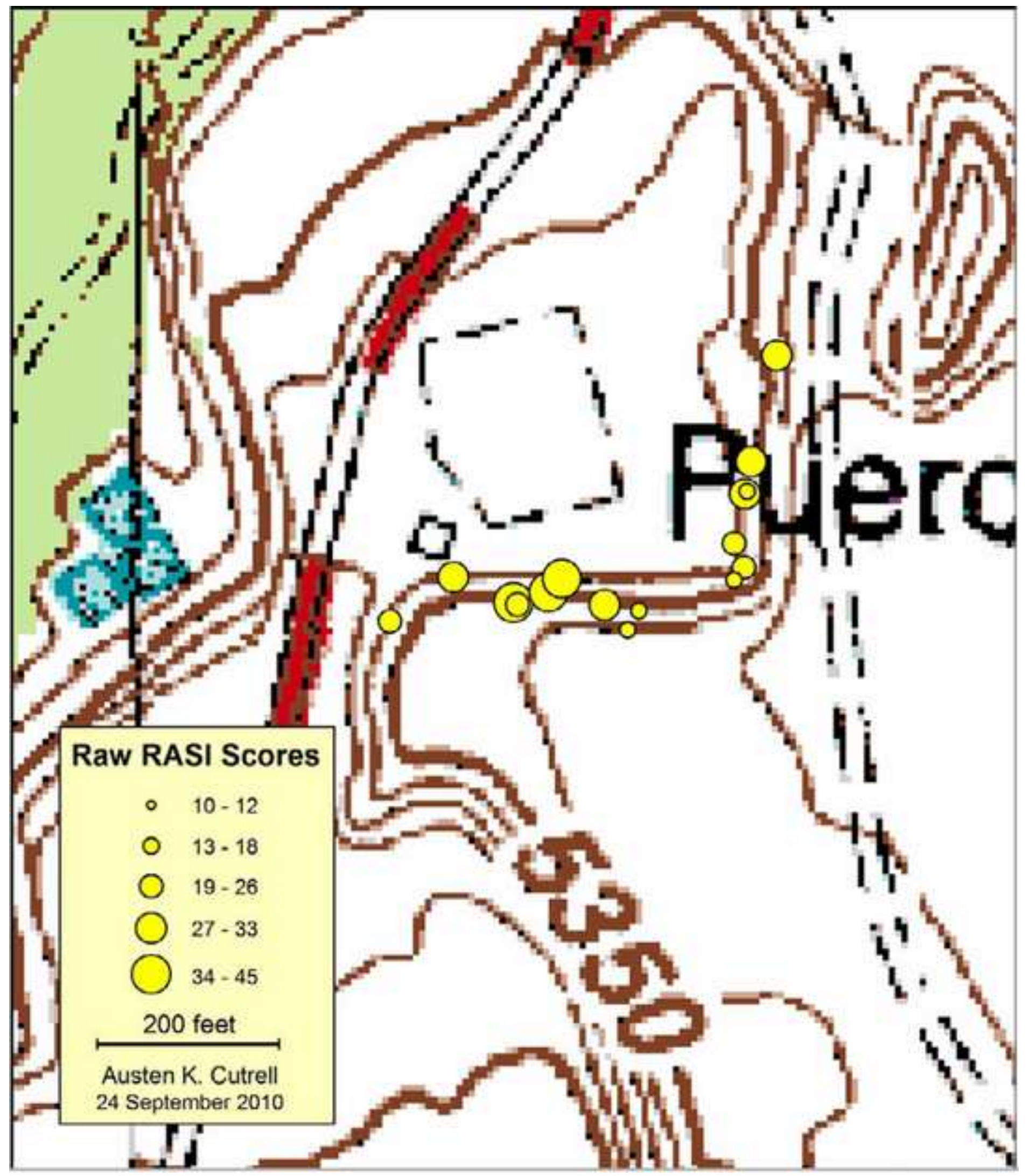




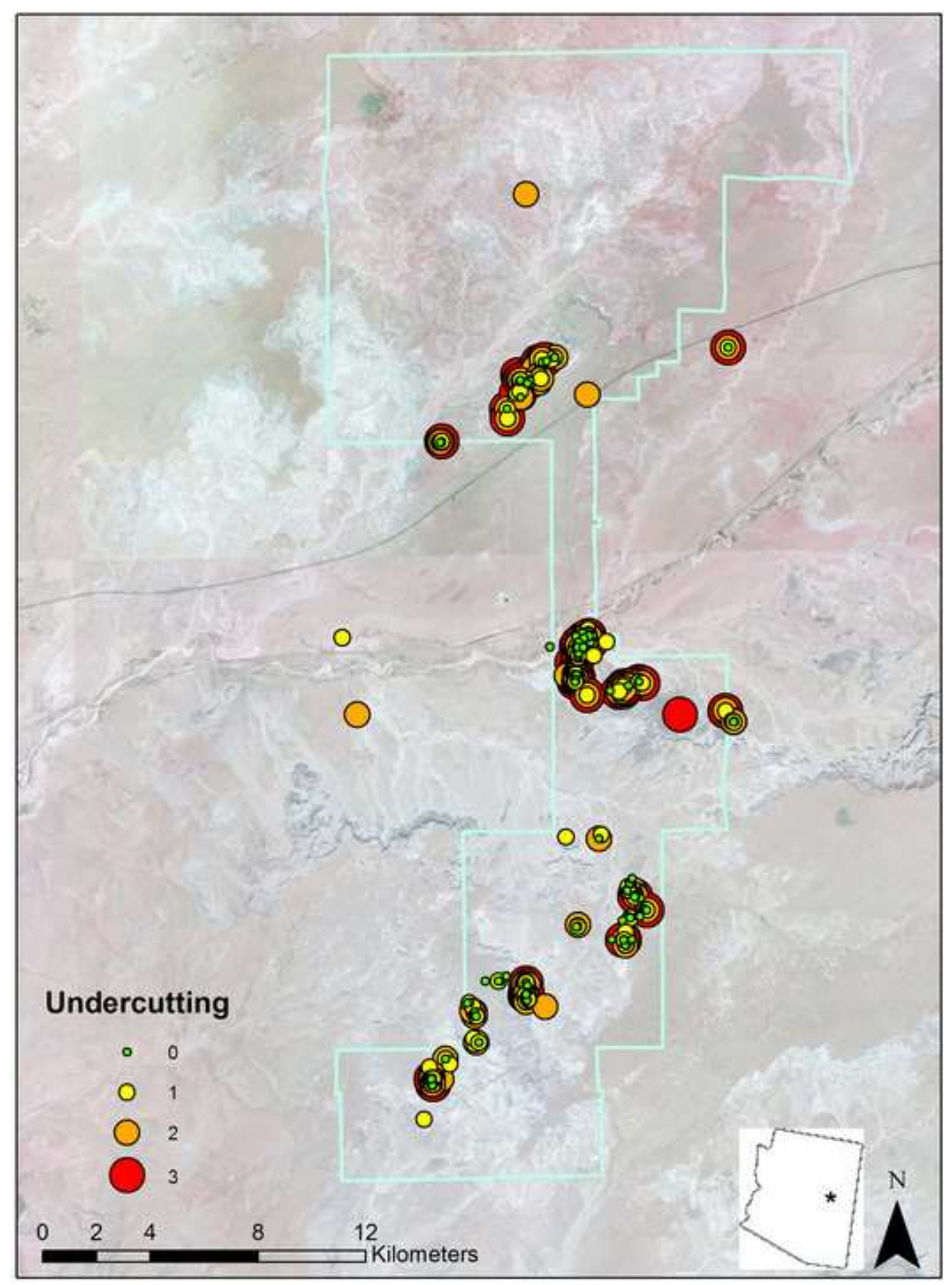




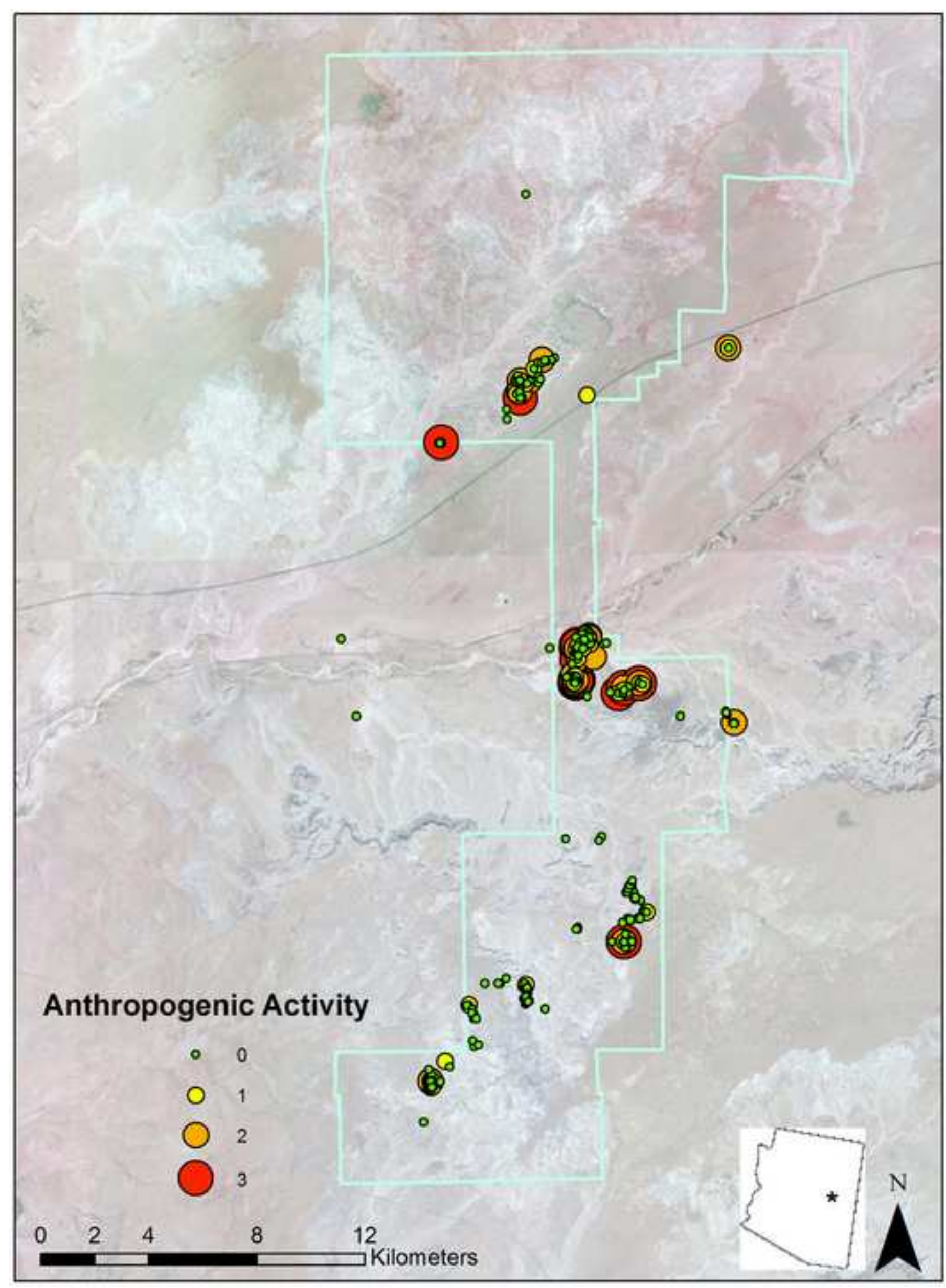



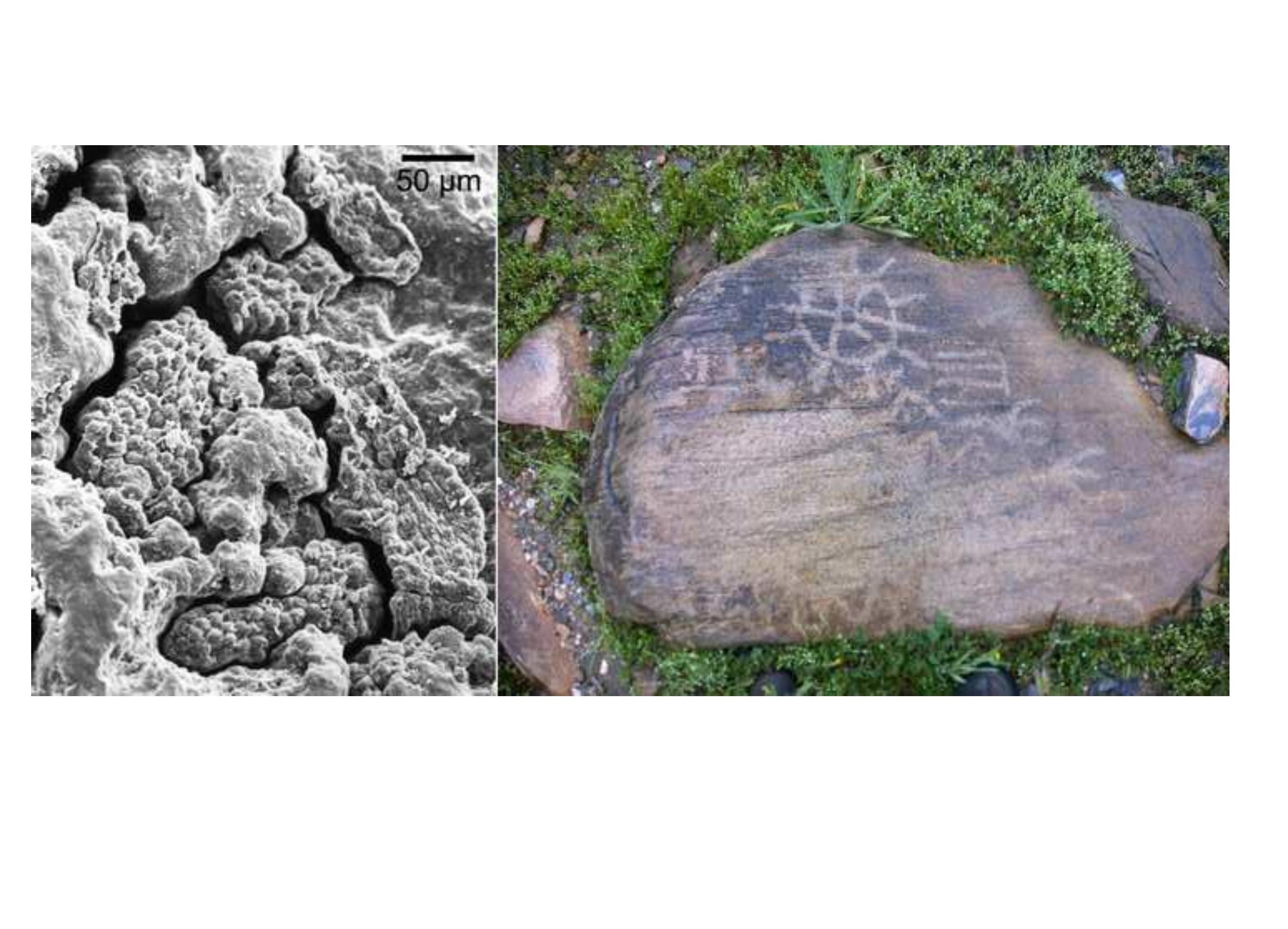

pep
py 